\title{
Thermophilic dark fermentation of sewage sludge for biohydrogen production - influence of $\mathrm{pH}$
}

\author{
Senturk i. ${ }^{{ }^{*}}$ and Buyukgungor H. ${ }^{2}$ \\ ${ }^{1}$ Sivas Cumhuriyet University, Department of Environmental Engineering, Sivas, 58140, Turkey \\ ${ }^{2}$ Ondokuz Mayis University, Department of Environmental Engineering, Samsun, 55270, Turkey \\ Received: 13/04/2018, Accepted: 27/08/2018, Available online: 26/09/2018 \\ *to whom all correspondence should be addressed: e-mail: ilknurg.senturk@gmail.com \\ https://doi.org/10.30955/gnj.002711
}

\section{Abstract}

This study investigates the usability of sewage sludge, waste from a waste water treatment facility, at the stable thermophilic temperature and different $\mathrm{pH}$ conditions in the biohydrogen production by dark fermentation. Without the addition of a pure hydrogen producer and nutrient source, the effect of a different constant $\mathrm{pH}$ in the range of $\mathrm{pH}$ 4-9 on biohydrogen production using sewage sludge was compared with that of a different initial $\mathrm{pH}$. It was understood from the results that biohydrogen production varies according to the characterization of sewage sludge. In the experiments, the lag time was insignificant ( $2 \mathrm{~h}$ ). The maximum hydrogen production was achieved at $\mathrm{pH} 5$ within the first 24-30 hours of fermentation (92894 $\mathrm{mL} \mathrm{m}^{-3} \mathrm{H}_{2}$ ). Therefore, it was determined that the higher digestion efficiencies of the sewage sludge were obtained at $\mathrm{pH} 5$. In general, with the increase in methanogens in the medium, the hydrogen producing ability and hydrogen content of the sewage sludge gradually decreased. Hydrogen production at almost all the $\mathrm{pH}$ values after the third day was less than $1000 \mathrm{~mL} \mathrm{~m}^{-3}$.

Keywords: Biohydrogen production, dark fermentation, initial $\mathrm{pH}$, sewage sludge, thermophilic condition.

\section{Introduction}

Hydrogen is known as a clean renewable energy source. The combustion of hydrogen produces no greenhouse gases, and has a high energy yield of $142.35 \mathrm{~kJ} \mathrm{~g}^{-1}$, which is 2.75 fold greater than that of hydrocarbon fuels (Cai et al., 2004; Guo et al., 2010). Currently, hydrogen is widely recognized as an ideal alternative source of energy to substitute fossil fuels as it is renewable and has a zero-pollutant-emission energy (Liu et al., 2011). Hydrogen generation can be classified in two ways: chemical-physical and biological methods. The chemicalphysical methods are energy intensive and expensive. In contrast, the biological methods are environmentally favorable and consume less energy (Cai et al., 2004).

Attention is very much focused on the hydrogen production from microbial conversion of industrial wastes and residues. This is not only because hydrogen is a clean energy, but also because it can be a process for waste reduction and reclamation. Alternative uses of wastes are encouraged to reduce environmental pollution. Sewage sludge from a wastewater treatment plant as a municipal solid waste is rich in carbohydrates and proteins and thus, it is a potential substrate for producing hydrogen (Guo et al., 2008; Senturk and Buyukgungor, 2010; Liu et al., 2011). Using sewage sludge as the substrate for fermentative hydrogen production offers several advantages over the use of other biomass sources. It is available at little or no cost (Nicolau et al., 2008). The prime advantage is expensive management and the disposal of sewage sludge can be surmounted. The amount required for disposal can be converted into credit against the cost of hydrogen production (Kotay and Das, 2010).

Anaerobic digestion is an appropriate technique for the reduction in the volume and weight of excess sludge before final disposal, and it is employed worldwide as the oldest and most important process for sludge stabilization. Hydrogen is an intermediary metabolite of anaerobic digestion, which is rapidly consumed and converted into other products by the hydrogen consumption of microorganisms in the third stage of anaerobic digestion. Anaerobic digestion can be operated at different temperatures: mesophilic $\left(25-40^{\circ} \mathrm{C}\right)$, thermophilic $\left(40-65^{\circ} \mathrm{C}\right)$, extreme-thermophilic $\left(65-80^{\circ} \mathrm{C}\right)$ or hyper-thermophilic $\left(>80^{\circ} \mathrm{C}\right)$ (Levin et al., 2004).

$\mathrm{H}_{2}$ production through sewage sludge is influenced by many factors, including the type of inoculum, pretreatment, $\mathrm{pH}$, temperature, and wastewater specificity (Tang et al., 2008). The results so far have indicated that the control of $\mathrm{pH}$ is crucial to hydrogen production due to the effects of the $\mathrm{pH}$ on the hydrogenase activity and/or on the metabolism pathways (Fang and Liu, 2002). Thus, it is important to control pH at an optimal range to maintain hydrogen production. On the other hand, if the $\mathrm{pH}$ is not maintained in the desired range, it could inhibit hydrogen production or cause a microbial population shift resulting in the cessation of hydrogen production (Khanal et al., 2004; 
Lin et al., 2011). Along with $\mathrm{pH}$, temperature is also an important environmental parameter which strongly affects biohydrogen production. Most of the studies on biohydrogen production are conducted under mesophilic and thermophilic conditions.

So far, very little work on fermentative hydrogen production from sewage sludge has been conducted. However, it should be noted that so far all these studies used pure cultures of bacteria as inoculum. Although this may result in higher yields it would be expensive and impractical to attempt at full scale due to the time, cost and energy requirements of preparing and storing enough bacterial biomass to seed a digester containing thousands of liters of sewage sludge. Despite this limitation however, work published so far has demonstrated the feasibility of producing hydrogen fermentatively from sewage sludge (Nicolau et al., 2008).

In the work reported here, the inoculum used to begin hydrogen production was provided directly from sewage sludge. The experiments were carried out not using additional anaerobic inoculum and extra nutrient without any pretreatment or enzyme addition to the sludge. Also, the sewage sludge properties are very important in this kind of studies. Content of treated municipal wastewater affect characteristics of sewage sludge. Hence hydrogen production is also affected. Obtained every result for this reason adds a different novelty to the literature. The present study is designed in order to investigate the usability of sewage sludge, waste from a waste water treatment facility, at the stable thermophilic temperature and different $\mathrm{pH}$ conditions in the biohydrogen production by dark fermentation.

\section{Materials and methods}

\subsection{Sewage sludge}

Sewage sludge used in the study was obtained from return sludge pumping station of the secondary sedimentation tank of a biological municipal wastewater treatment plant located in Samsun, Turkey and its main characteristics are shown in Table 1 . The sludge was first concentrated by settling at $4^{\circ} \mathrm{C}$ for about 2-3 days, and the sediments were stored at $4^{\circ} \mathrm{C}$ before being used (Wang et al., 2003).

Table 1. Mean characteristics of sewage sludge used in experiments

\begin{tabular}{cc}
\hline Item & Value $\left(\mathbf{m g ~ L}^{-1}\right)$ \\
\hline $\mathrm{pH}$ & $6.59 \pm 0.19$ \\
\hline Total chemical oxygen demand (TCOD) & $16394.00 \pm 2615.04$ \\
\hline $\begin{array}{c}\text { Soluble chemical oxygen demand } \\
\text { (SCOD) }\end{array}$ & $315.96 \pm 242.85$ \\
\hline Total protein & $7037.17 \pm 1702.87$ \\
\hline Soluble protein & $157.00 \pm 79.53$ \\
\hline Total carbohydrate & $1473.69 \pm 518.30$ \\
\hline Soluble carbohydrate & $16.46 \pm 6.36$ \\
\hline Total solid (TS) & $17785 \pm 3585.00$ \\
\hline Volatile solid (VS) & $12322.78 \pm 2137.45$ \\
\hline Volatile fatty acid $\left(\mathrm{mg} \mathrm{CH}{ }_{3} \mathrm{COOH} / \mathrm{L}\right)$ & $1144 \pm 205.68$ \\
\hline
\end{tabular}

\subsection{Dark fermentative hydrogen production}

The sewage sludge was used as the substrate and the seed without the addition of a pure hydrogen producer for hydrogen production in the experiment. Experiments of biohydrogen production from sewage sludge by fermentation were carried out in a 2-liter bioreactor with a working volume of $750 \mathrm{~mL}$. Before the sludge samples were used to anaerobic fermentation, the $\mathrm{pH}$ value of sludge samples was adjusted to $4,5,6,7,8,9$ respectively by adding $2 \mathrm{M}$ hydrochloric acid $(\mathrm{HCl})$ or $4 \mathrm{M}$ sodium hydroxide $(\mathrm{NaOH})$. The $\mathrm{pH}$ adjusted sludge samples (750 $\mathrm{mL}$ ) were added into 2-liter bioreactor, respectively. No extra nutrients were added into the tested sludge. The bioreactor was equipped with two ports for gas and sludge sampling (Figure 1a-1b). Before fermentation, the internal part of the reactor was purged with nitrogen gas for 3 minutes to provide anaerobic conditions. After quickly sealed, the reactor was placed into an incubator operating at $45^{\circ} \mathrm{C}$ and $150 \mathrm{rpm}$. In the whole process; $\mathrm{pH}, \mathrm{COD}$, protein and carbohydrate concentrations of the influent and the effluent with the hydrogen and methane concentration were monitored every day. The anaerobic digestion was continued until hydrogen production stopped or decreased (Senturk and Buyukgungor, 2017).

\subsection{Analytical methods}

During incubation, biogas production was measured periodically by displacement of saturated aqueous $10 \%$ $\mathrm{NaCl}$ with $2 \% \mathrm{H}_{2} \mathrm{SO}_{4}$ in a graduated cylinder. The biogas in the headspace of digesters was sampled with a $1 \mathrm{~mL}$ gastight syringe. The hydrogen and methane contents of biogas were analyzed by a gas chromatograph (Shimadzu, GC-2010) equipped with a thermal conductivity detector (TCD) and $\mathrm{Rt}^{\circledR}$ - Msieve 5A (19723) capillary column. The temperatures of injector, detector and column were kept at $200^{\circ} \mathrm{C}, 200^{\circ} \mathrm{C}$ and $70^{\circ} \mathrm{C}$, respectively. Helium gas was used as the carrier gas with a flow rate of $19.3 \mathrm{~mL}$ $\mathrm{min}^{-1}$. The concentration of hydrogen and methane was tested frequently during fermentation and the biogas production was also recorded during the whole examination. The measured values were expressed as $\mathrm{mL}$ $\mathrm{m}^{-3}\left(\mathrm{ppmv}=\right.$ gas gas $\left.{ }^{-1}\right)$. With samples obtained before and after fermentation, characteristics of the sludge in the fermenter were identified (Senturk and Buyukgungor, 2017a).

The $\mathrm{pH}$ of sludge was measured by a $\mathrm{pH}$ meter (Sartorius PB-20). The total COD and soluble COD concentrations of sludge were determined with closed reflux titrimetric method according to the standard method (APHA, 2005). Total and soluble proteins in the liquid phase were measured by the Lowry's method using bovine serum albumin as a standard solution (Lowry et al., 1951), total and soluble carbohydrates by the phenol-sulfuric acid method using glucose as a standard solution (Dubois et al., 1956). The samples were filtered through a $0.45 \mu \mathrm{m}$ membrane and centrifuged at $4000 \mathrm{rpm}$ for $30 \mathrm{~min}$ before determining the concentrations of SCOD, soluble protein, and soluble carbohydrate. 


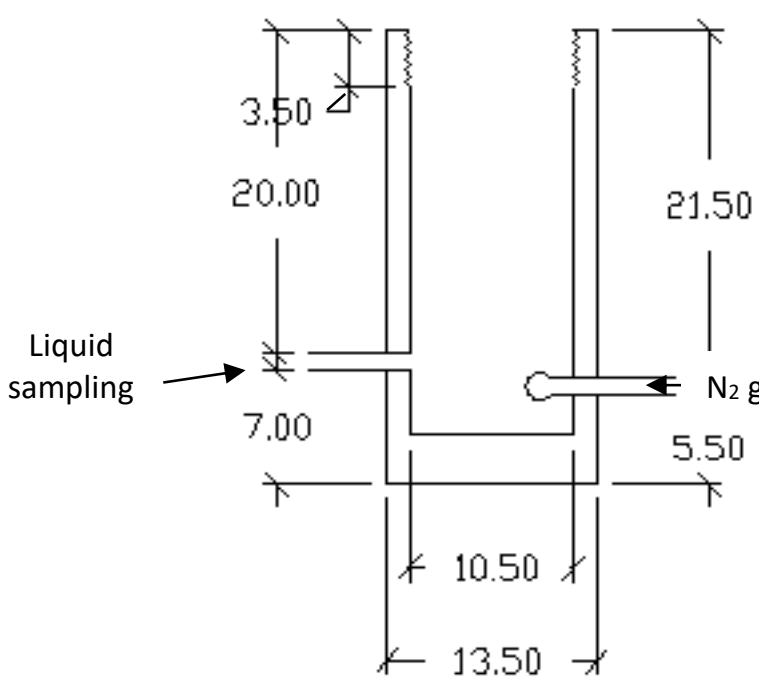

a) Reactor

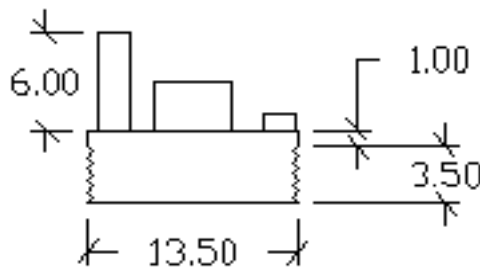

c) Front view of the cover

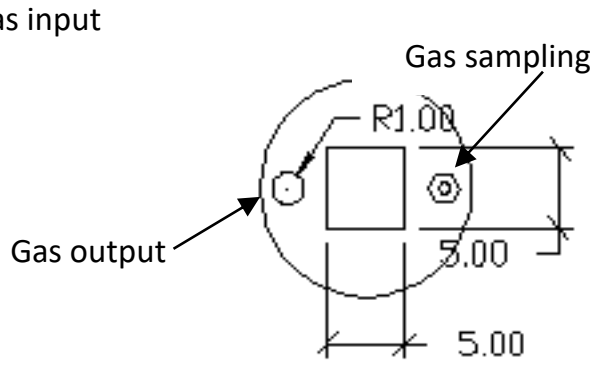

b) Top view of the cover

Figure 1a. Reactor used in fermentation experiments

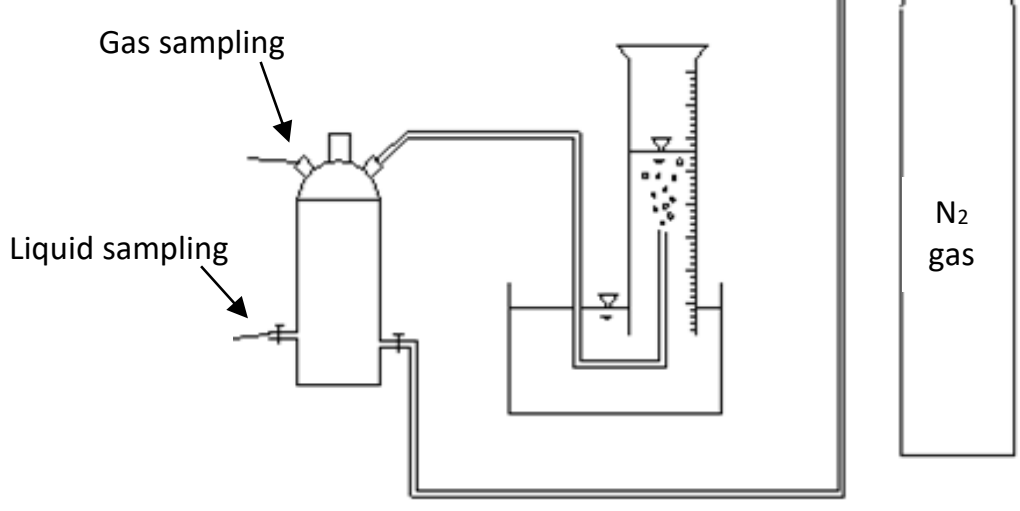

Figure 1b. Experimental set-up

\section{Results and discussion}

\subsection{Effect of initial $\mathrm{pH}$ on solubilization of sewage sludge}

Many factors such as temperatures and the initial $\mathrm{pH}$ can influence the fermentative hydrogen production because they can affect the activity of hydrogen-producing bacteria by influencing the activity of some essential enzymes such as hydrogenases for the fermentative hydrogen production. It has been demonstrated by various one-factor-at-a-time experiments that in an appropriate range, increasing temperatures and the initial $\mathrm{pH}$ respectively could increase the ability of hydrogen-producing bacteria to produce hydrogen (Wang and Wan, 2011).

The effects of $\mathrm{pH}$, the content of the sewage sludge in the reactor and the changes occurring in the reactor at the time of biohydrogen production from the sewage sludge via anaerobic fermentation were investigated in studies conducted in a thermophilic temperature. During the sludge fermentation for the biohydrogen production, these organic materials usually undergo solubilization, hydrolysis, and acidification. The changes in the soluble protein and carbohydrate were applied in the current study to express the solubilization of the sludge's main 
particulate organic matters. The results obtained are described in detail below.

Due to hydrolysis, the total protein and total carbohydrates concentrations increased within the first $24 \mathrm{~h}$ at $\mathrm{pH}$ 4. However, as the fermentation process progressed, there was a decrease in the total protein and the total carbohydrates concentration and increased $C_{0} / C$ ratios (Table 2). The changes occurring in the concentrations during the fermentation are due to the balance between the amounts consumed and released from the solid phase. Hydrolysis, a phase occurring between anaerobic fermentation and biohydrogen production, plays an important role in the release of organic matters in the solid phase (Chen et al., 2002).

Table 2. The change in total matter concentrations versus time at different $\mathrm{pH}$ values

\begin{tabular}{|c|c|c|c|c|}
\hline & \multirow[b]{2}{*}{ Total matter } & \multicolumn{3}{|c|}{$\mathrm{C}_{\mathrm{o}} / \mathrm{C}$ ratio } \\
\hline & & $24 \mathrm{~h}$ & $48 \mathrm{~h}$ & $72 \mathrm{~h}$ \\
\hline \multirow{5}{*}{$\mathrm{pH} 4$} & Protein & 0.64 & - & 1.05 \\
\hline & Carbohydrates & 0.89 & - & 1.61 \\
\hline & COD & 1.08 & - & 1.86 \\
\hline & Mean & 0.87 & & 1.5067 \\
\hline & Std. Deviation & 0.22068 & & 0.41477 \\
\hline \multirow{5}{*}{ pH 5} & Protein & 1.74 & 2.07 & 2.92 \\
\hline & Carbohydrates & 1.06 & 1.19 & 1.25 \\
\hline & COD & 1.00 & 1.09 & 1.09 \\
\hline & Mean & 1.2667 & 1.45 & 1.7533 \\
\hline & Std. deviation & 0.41102 & 0.53926 & 1.01353 \\
\hline \multirow{5}{*}{ pH 6} & Protein & 0.98 & 0.87 & - \\
\hline & Carbohydrates & 1.46 & 1.60 & - \\
\hline & COD & 1.03 & 1.03 & - \\
\hline & Mean & 1.1567 & 1.1667 & \\
\hline & Std. Deviation & 0.26388 & 0.38371 & \\
\hline \multirow{5}{*}{$\mathrm{pH} 7$} & Protein & 0.98 & 0.92 & 1.23 \\
\hline & Carbohydrates & 1.63 & 1.70 & 1.55 \\
\hline & COD & 1.27 & 1.27 & 1.48 \\
\hline & Mean & 1.2933 & 1.2967 & 1.42 \\
\hline & Std. deviation & 0.32563 & 0.39068 & 0.16823 \\
\hline \multirow{5}{*}{$\mathrm{pH} 8$} & Protein & 1.06 & 1.24 & 1.33 \\
\hline & Carbohydrates & 1.27 & 1.23 & 1.81 \\
\hline & COD & 1.60 & 2.00 & 2.51 \\
\hline & Mean & 1.31 & 1.49 & 1.8833 \\
\hline & Std. deviation & 0.27221 & 0.4417 & 0.59341 \\
\hline \multirow{5}{*}{ pH 9} & Protein & 1.28 & 1.34 & - \\
\hline & Carbohydrates & 1.16 & 1.50 & - \\
\hline & COD & 1.11 & 1.11 & - \\
\hline & Mean & 1.1833 & 1.3167 & \\
\hline & Std. Deviation & 0.08737 & 0.19604 & \\
\hline
\end{tabular}

Unread $C_{o}=$ Initial total matter concentration $C=$ total matter concentration at any time

Studies have shown that the increases in the soluble matter concentration positively affect the hydrogen production from sewage sludge (Nicolau et al., 2008; Kotay and Das, 2009; Guo et al., 2010). In the study conducted at $\mathrm{pH} 5$, when the reactor content against time was examined, we see a decrease in total protein, total carbohydrates, and TCOD concentrations during fermentation (Table 2). The concentration of the dissolved matter showed an alteration as shown in Table 3 . While soluble carbohydrates and SCOD concentrations continued to increase during the fermentation, the soluble protein began to decrease after a time period of 24 hours. The increase in soluble protein within the first 24 hours, as seen in Figure 2, affected the hydrogen production positively.

Table 3. The change in soluble matter concentrations versus time at different $\mathrm{pH}$ values

\begin{tabular}{|c|c|c|c|c|}
\hline & \multirow[b]{2}{*}{ Soluble matter } & \multicolumn{3}{|c|}{$\mathrm{C}_{\mathrm{o}} / \mathrm{C}$ ratio } \\
\hline & & $24 h$ & $48 \mathrm{~h}$ & $72 \mathrm{~h}$ \\
\hline \multirow{5}{*}{$\mathrm{pH} 4$} & Protein & 0.68 & - & 0.98 \\
\hline & Carbohydrates & 0.31 & - & 0.22 \\
\hline & COD & 0.29 & - & 0.22 \\
\hline & Mean & 0.4267 & & 0.4733 \\
\hline & Std. deviation & 0.21962 & & 0.43879 \\
\hline \multirow{5}{*}{ pH 5} & Protein & 0.59 & 1.24 & 1.65 \\
\hline & Carbohydrates & 0.18 & 0.17 & 0.12 \\
\hline & COD & 0.07 & 0.06 & 0.05 \\
\hline & Mean & 0.28 & 0.49 & 0.6067 \\
\hline & Std. deviation & 0.27404 & 0.65184 & 0.90423 \\
\hline \multirow{5}{*}{ pH 6} & Protein & 0.59 & 0.75 & - \\
\hline & Carbohydrates & 0.10 & 0.10 & - \\
\hline & COD & 0.08 & 0.04 & - \\
\hline & Mean & 0.2567 & 0.2967 & \\
\hline & Std. deviation & 0.28885 & 0.39374 & \\
\hline \multirow{5}{*}{$\mathrm{pH} 7$} & Protein & 1.04 & 1.15 & 1.87 \\
\hline & Carbohydrates & 0.16 & 0.15 & 0.12 \\
\hline & COD & 0.12 & 0.06 & 0.08 \\
\hline & Mean & 0.44 & 0.4533 & 0.69 \\
\hline & Std. deviation & 0.52 & 0.60501 & 1.02211 \\
\hline \multirow{5}{*}{$\mathrm{pH} 8$} & Protein & 0.21 & 0.22 & 0.63 \\
\hline & Carbohydrates & 0.20 & 0.13 & 0.19 \\
\hline & COD & 0.02 & 0.03 & 0.09 \\
\hline & Mean & 0.1433 & 0.1267 & 0.3033 \\
\hline & Std. deviation & 0.10693 & 0.09504 & 0.28729 \\
\hline \multirow{5}{*}{ pH 9} & Protein & 0.28 & 0.32 & - \\
\hline & Carbohydrates & 1.37 & 0.74 & - \\
\hline & COD & 0.20 & 0.20 & - \\
\hline & Mean & 0.6167 & 0.42 & \\
\hline & Std. dDeviation & 0.65363 & 0.28355 & \\
\hline
\end{tabular}

Unread $C_{o}=$ Initial soluble matter concentration $C=$ soluble matter concentration at any time

The general result obtained from the studies conducted at $\mathrm{pH} 6,7,8$ and 9 respectively is conclude that the total protein, total carbohydrates, and TCOD concentrations change with time. The soluble matter concentrations generally showed increases in the first 24 hours of fermentation. However, after 24 hours the soluble protein concentration decreased at all the $\mathrm{pH}$ values while the carbohydrates and COD concentration either increased or did not change. The increase in the solute COD and carbohydrate concentration did not have an effect on 
enhancing the hydrogen production, indicating that the soluble protein was effective in the hydrogen production in the first 24 hours.

When Table 3 was examined, despite some exceptions (at $\mathrm{pH}$ 7, the soluble protein concentration continuously decreased during the fermentation), it was observed that the amount of soluble nutrients released from the solid phase of the sewage sludge was higher during the hydrogen fermentation. However, these results do not show any parallelism with the hydrogen production graph in Figure 2. Therefore, it is clear that all the organic matter released from the sewage sludge did not convert into hydrogen through anaerobic fermentation. Similar results were reported by Guo et al. (2010). In their study, Guo et al. (2010) performed fermentation tests by using pretreated sewage sludge via sterilization and filtrate obtained from the sludge. The amount of organic matter released from the filtrate was less than that released from the sludge during fermentation. However, the hydrogen yield from filtrate was higher than that obtained from the sludge and this suggested that not all the dissolved organic matter was converted into hydrogen.

For statistical evaluation of the change in soluble and total matter concentrations versus time at different $\mathrm{pH}$ values, the one-way analysis of variance (ANOVA) test was conducted to test the significance of experimental data shown in Tables 2 and 3. The corresponding ANOVA for Tables 2 and 3 showed that the F-values were 1.015, 0.305 and 0.350 , respectively. It implies that the data were statistically not significant because $\mathrm{P}>0.05$ ( $\alpha$-level) (Table 4).

3.2. The effect on the production of $\mathrm{H}_{2}$ and $\mathrm{CH}_{4}$ in the change in the concentration of the soluble matter in the reactor at different $\mathrm{pHs}$

For the biohydrogen production, the soluble organics are very important since the hydrogen producing microorganisms need to use them in order to grow and produce hydrogen (BenYi and JunXin, 2009). Among all the organic solid matters, carbohydrates are the compounds which undergo the maximum degradation during the anaerobic fermentation. However, proteins and lipids also contribute to hydrogen production to some extent. In this study, we observed that the dissolution of the carbohydrates was higher than that of the proteins during the fermentation.

Proteins are the principal constituents of an animal organism and they contain carbon, which is common in all organic substances, as well as in hydrogen and oxygen. In addition, they contain as their distinguishing characteristic, a fairly high and constant proportion of nitrogen. In many cases sulfur, phosphorus, and iron are also constituents. Therefore, the efficiency of anaerobic fermentation is expected to increase with the increase in soluble protein concentration (Nah et al., 2000). As clearly seen from Figure 2, the increase in soluble protein concentrations within the first 24 hours increased the hydrogen production.

Table 4. ANOVA for the change in soluble and total matter concentrations versus time different $\mathrm{pH}$ values

\begin{tabular}{|c|c|c|c|c|c|c|c|}
\hline & Parameters & Source of variation & SS & DF & MS & F-value & P-value \\
\hline \multirow{9}{*}{ Total matter } & $24 \mathrm{~h}$ & Groups $_{\text {between }}$ & .402 & 5 & .080 & 1.015 & .451 \\
\hline & & Groups $_{\text {within }}$ & .950 & 12 & .079 & & \\
\hline & & Total & 1.352 & 17 & & & \\
\hline & $48 \mathrm{~h}$ & Groups between & .201 & 4 & .050 & .305 & .868 \\
\hline & & Groups $_{\text {within }}$ & 1.648 & 10 & .165 & & \\
\hline & & Total & 1.849 & 14 & & & \\
\hline & $72 \mathrm{~h}$ & Groups between & .415 & 3 & .138 & .350 & .790 \\
\hline & & Groups $_{\text {within }}$ & 3.159 & 8 & .395 & & \\
\hline & & Total & 3.574 & 11 & & & \\
\hline \multirow{9}{*}{ Soluble matter } & $24 \mathrm{~h}$ & Groups between & .422 & 5 & .084 & .553 & .734 \\
\hline & & Groups $_{\text {within }}$ & 1.832 & 12 & .153 & & \\
\hline & & Total & 2.254 & 17 & & & \\
\hline & $48 \mathrm{~h}$ & Groups between & .263 & 4 & .066 & .317 & .860 \\
\hline & & Groups $_{\text {within }}$ & 2.071 & 10 & .207 & & \\
\hline & & Total & 2.334 & 14 & & & \\
\hline & $72 \mathrm{~h}$ & Groups between & .257 & 3 & .086 & .160 & .920 \\
\hline & & Groups $_{\text {within }}$ & 4.275 & 8 & .534 & & \\
\hline & & Total & 4.531 & 11 & & & \\
\hline
\end{tabular}

SS, sum of squares; DF, degrees of freedom; MS, mean square 


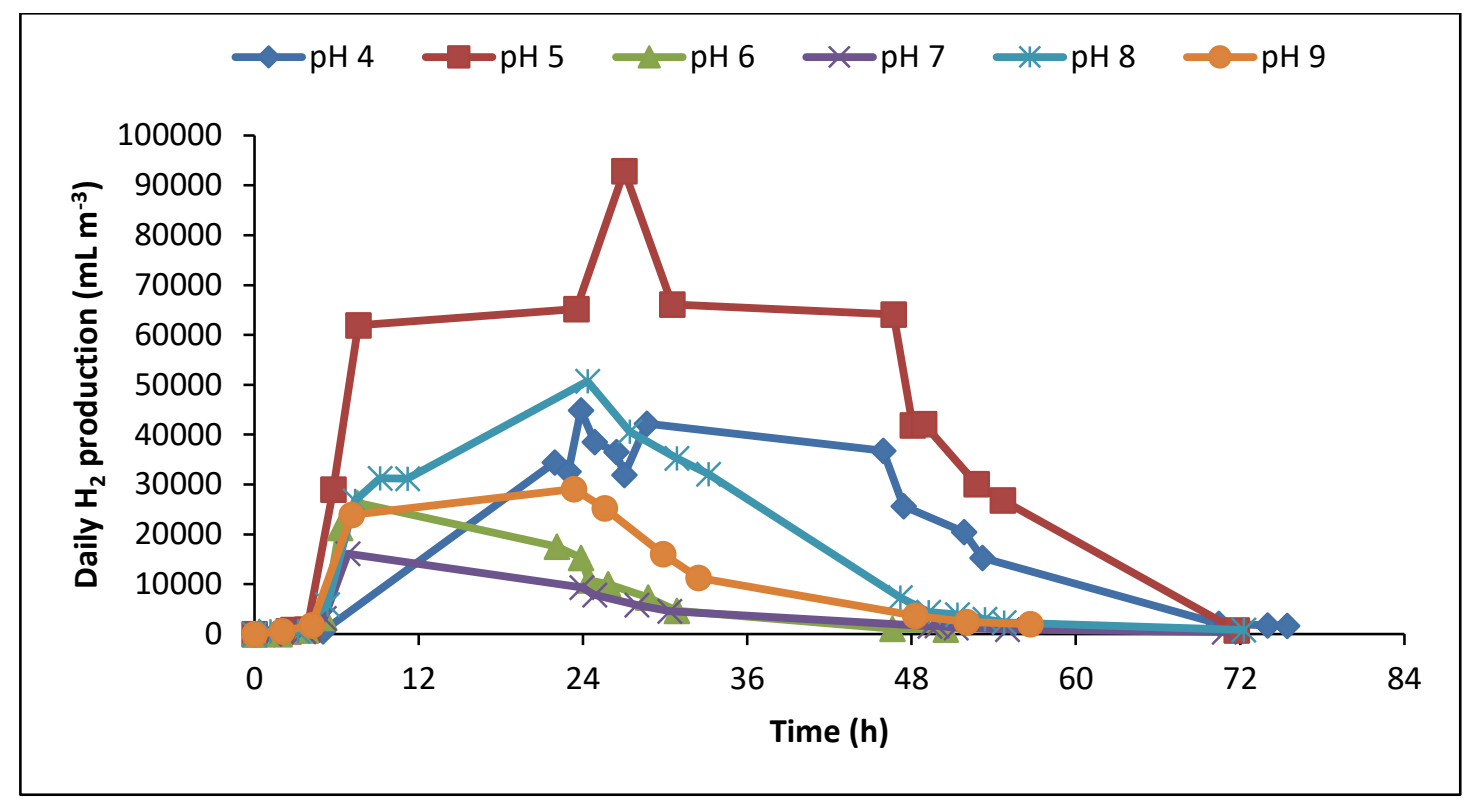

Figure 2. Effect of different initial pH on hydrogen production during sludge fermentation

Again, as seen from the studies, soluble protein concentration shows increases at the beginning of hydrogen production fermentation. However, the protein concentration decreased with time during fermentation due to soluble protein being used for hydrogen production. An alteration in the soluble carbohydrates content during fermentation is similar to that in protein. However, while the amount of released soluble carbohydrates increases, the total amount of carbohydrate reduces, and the hydrogen production becomes slightly lower when compared to the use of proteins, which shows that the organic matter used for hydrogen production in the sewage sludge is protein and then carbohydrate. Guo et al., 2008 used pretreated sludge and Pseudomonas sp. GZ1 (EF551040) for hydrogen production via anaerobic fermentation. Similarly, they reported that protein fermentation was more effective in hydrogen production.

In their study, Xiao and Liu (2009) reported that the hydrogen production stage was associated with the decrease in the dissolved carbohydrate concentration and carbohydrates were the main material for hydrogen production via anaerobic fermentation. Nicolau et al. (2008) indicated that carbohydrate fermentation to hydrogen is a source of hydrogen production in the anaerobic fermentation of sewage sludge. These results are different from those obtained from Cai et al. (2004) and Guo et al. (2008). These different results obtained from these studies can be attributed to the different types of substrate and inoculums used in hydrogen production and their sources (Xiao and Liu, 2009).

In Figure 2, hydrogen concentrations obtained as a result of anaerobic fermentation studies conducted at $45^{\circ} \mathrm{C}$ with different initial $\mathrm{pH}$ values are given. In contrast to the results obtained by Cheng et al. (2000) by using longer lag periods such as $66 \mathrm{~h}$, the lag periods in this study are insignificant for anaerobic fermentation ( $\sim 2 \mathrm{~h})$.
The chemical and biological content of the substrate may have led to the shortening of the time. In all the $\mathrm{pH}$ tests, the hydrogen concentration in the gas phase showed a fluctuating curve with peaks observed between 7 and 24 hours. This shows that a significant amount of hydrogen produced is consumed somewhat. Usually at very low hydrogen concentrations, the hydrogen consuming methanogenic bacteria can convert the formed hydrogen to methane if the methanogenesis step goes smoothly. This also causes a rapid decrease in the amount of hydrogen (Cai et al., 2004).

In these tests, after a 1-2 hour lag time, it was observed that the hydrogen content increased in time and the hydrogen gas release showed an increase after a period of approximately 4-5 hours. However, especially at $\mathrm{pH} 6$ and 7 , the hydrogen concentration rapidly decreased after 7-8 hours. At pH 8 and 9, the concentration was higher compared to $\mathrm{pH} 6$ and 7. However, at the end of 24 hours, the hydrogen began to decrease at these $\mathrm{pH}$ values. At $\mathrm{pH}$ 4 and 5 , a decrease in the hydrogen concentration was observed at the end of 48 hours. At pH 5, the highest hydrogen gas concentration was read. The hydrogen gas release remained at higher levels and lasted longer when compared to $\mathrm{pH}$ 4. Overall, the hydrogen content decreased monotonically over time and dropped below $1000 \mathrm{~mL} \mathrm{~m}^{-3}$ at almost all pHs at the end of 3 days.

Figure 3 provides the amount of methane concentration in the reactor during anaerobic fermentation. In all the $\mathrm{pH}$ studies, significant increases were observed in the methane concentration after 24 hours. At $\mathrm{pH} 6$, approximately $90000 \mathrm{~mL} \mathrm{~m}^{-3}$ of methane was produced at the end of the 28-29 hour of the fermentation, which is the highest concentration obtained in all tests. The amount of methane produced from the sewage sludge after a 48 hour of fermentation, as seen from Figure 3, is as follows; $\mathrm{pH} 6>\mathrm{pH} 9>\mathrm{pH} 7>\mathrm{pH} 5>\mathrm{pH} 8>\mathrm{pH} 4$. The active methane bacteria in the environment leads to a 
depletion of hydrogen gas in the reactor, and thus, the hydrogen gas concentration decreased in a short time. Although sewage sludge produces hydrogen, microorganisms in the sewage sludge consume hydrogen rapidly.

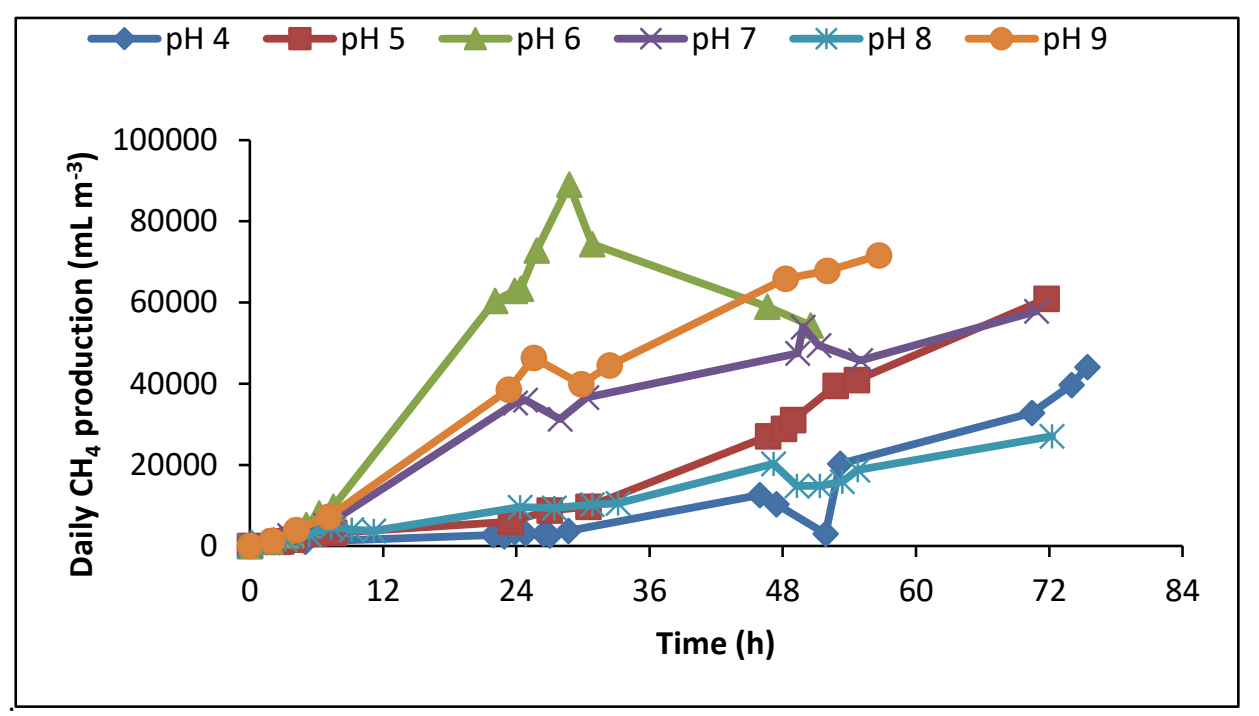

Figure 3. Effect of different initial pH on methane production during sludge fermentation

As is known, the anaerobic fermentation process of waste water or the waste biosolid involves three stages as hydrolysis, acidification, and methane production. Hydrogen is produced in the acidification step and $\mathrm{pH}$ affects biohydrogen fermentation. In the hydrolysis step, the $\mathrm{pH}$ is reduced. In the acidification, namely hydrogen production step, the $\mathrm{pH}$ increases and remains constant (Cai et al., 2004).

Chen et al. (2002) indicated that the proper pH level could shorten the lag time and be useful for producing hydrogen in acclimating anaerobic microorganisms; $\mathrm{pH}$ 6.5-7.0 was the best levels for enhancing the hydrogen production. Cai et al. (2004) performed their studies in a serum bottle (a volume of $125 \mathrm{~mL}$ ). They used waste water as the substrate without adding extra nutrients or seed and studied at $36 \pm 1^{\circ} \mathrm{C}$ at $150 \mathrm{rpm}$ and $\mathrm{pH} 3-12.5$. The final $\mathrm{pH}$ decreased at the initial $\mathrm{pH}$ of $7.0-12.5$, but increased at the initial $\mathrm{pH}$ of 3.0-6.0.

Similarly, as a result of the fermentation experiments conducted at $45^{\circ} \mathrm{C}$, we observed that when the initial $\mathrm{pH}$ is between 7 and 9, the $\mathrm{pH}$ value decreased at the end of the fermentation, but increased at the $\mathrm{pH}$ values ranging from 4 to 6 . The differences in the change of $\mathrm{pH}$ were concerned with the SCOD of the sludge samples since the productions of the VFA and $\mathrm{NH}_{4}{ }^{+}-\mathrm{N}$ is the result of the organics (SCOD) degradation (BenYi and JunXin, 2009).

In all the tests, at the end of 2-3 hours, the hydrogen production began. Depending on the initial $\mathrm{pH}$, the hydrogen production at the end of 24 hours is as follows; $\mathrm{pH} 5>\mathrm{pH} 8>\mathrm{pH} 4>\mathrm{pH} 9>\mathrm{pH} 6>\mathrm{pH}$ 7. The maximum yield was obtained at the 24-30th hours of fermentation at $\mathrm{pH}$ $5\left(92894 \mathrm{~mL} \mathrm{~m}^{-3} \mathrm{H}_{2}\right)$. However, the hydrogen accumulated in the upper part of the reactor, is consumed by hydrogen consumers in the upcoming days of fermentation. At $\mathrm{pH} 6$, 7 and 9 , a rapid consumption in the amount of hydrogen in the reactor was observed after the first 4 hours. At the same time, the highest methane production was obtained at $\mathrm{pH} 6, \mathrm{pH} \mathrm{9}$, and $\mathrm{pH} 7$, respectively. The hydrogen gas production and consumption ranking revealed that better results were obtained in studies using the initial $\mathrm{pH}$ value of 5 . Although hydrogen is produced at $\mathrm{pH} 8$, a rapid decrease was observed in the hydrogen production in a short period of time. The studies in the literature support our results. The $\mathrm{pH}$ values of 5 and 6 were preferred in most of the studies on fermentative hydrogen production (Nicolau et al., 2008).

The $\mathrm{pH}$ value also influences the solubility of organic matters found in sewage sludge structure. In this study, high solubility was obtained at $\mathrm{pH} 5$ when compared to other $\mathrm{pH}$ values. At $\mathrm{pH} \mathrm{5,} \mathrm{the} \mathrm{protein,} \mathrm{carbohydrate,} \mathrm{and}$ COD in the structure of the sewage sludge in the reactor become more soluble with increased hydrogen production efficiency. Additionally, because methanogenic activity reduces or stops at the $\mathrm{pH}$ values lower than 6.3, the methanogenic activity is expected to be inhibited at $\mathrm{pH}$ below 6 . Not surprisingly, the methane concentration remained at lower levels at $\mathrm{pH} 4$ and 5 (Figure 3).

Considering these results and the hydrogen production graph given in Figure 2, it was concluded that setting the $\mathrm{pH}$ of reactor contents to 5 would be appropriate.

\section{Conclusions}

In light of all the information given throughout this paper, wastewater sewage sludge was preferred as a raw material for biohydrogen production under thermophilic conditions via anaerobic fermentation. Total and dissolved substances are used to meet the nutritional needs of microorganisms in the fermentor, and consequently this also increases its hydrogen production efficiency. 
In particular, an increase in the amount of soluble protein positively affected the hydrogen production within the first 24 hours.

Another important factor affecting hydrogen production is the SCOD/TCOD ratio. However, this increase is not directly proportional. In this study conducted under thermophilic conditions, solubility was higher at $\mathrm{pH} 5$ in comparison to other $\mathrm{pH}$ values suggesting that $\mathrm{pH} 5$ is more appropriate for biohydrogen production. At an initial $\mathrm{pH}$ 5.0, the maximum cumulative biohydrogen production ( $92894 \mathrm{~mL} \mathrm{~m}^{-3} \mathrm{H}_{2}$ ) was attained. The favorable initial $\mathrm{pH}$ for hydrogen producing anaerobic bacteria was found to be 5.0. It was also concluded that the characteristics of wastewater and the initial $\mathrm{pH}$ affected the fermentative biohydrogen production.

The results obtained in this study are useful for designing $\mathrm{pH}$ operating conditions for an anaerobic reactor in order to produce biohydrogen. Future studies should continue investigating the issues such as the removal of the hydrogen consuming microorganisms from the reactor, the delay in the methane production, and increment of the solubility of the substance in the fermentor.

\section{Acknowledgments}

The authors thank Ondokuz Mayis University, Scientific Research Project Funding (OMU BAP) for their financial support [Project number: PYO.MUH.1904.12.006].

\section{References}

APHA. (2005), Standard Methods for the Examination of Water and Wastewater. 20th ed., American Public Health Association, Washington, D.C.

BenYi X. and JunXin L. (2009), Effects of various pretreatments on biohydrogen production from sewage sludge, Chinese Science Bulletin, 54, 2038-2044.

Cai M.L., Liu J.X. and Wei Y.S. (2004), Enhanced biohydrogen production from sewage sludge with alkaline pretreatment, Environmental Science \& Technology, 38, 3195-3202.

Chen C.C., Lin C.Y. and Lin M.C. (2002), Acid-base enrichment enhances anaerobic hydrogen production process, Applied Microbiology and Biotechnology, 58(2), 224-228.

Cheng S.S., Bai M.D., Chang S.M., Wu K.L. and Chen W.C. (2000), Studies on the Feasibility of Hydrogen Production Hydrolyzed Sludge by Anaerobic Microorganisms. The Twenty-fifth Wastewater Technology Conference, Yunlin, Taiwan (in Chinese).

Dubois M., Gilles K.A., Hamilton J.K., Rebers P.A. and Smith F. (1956), Colorimetric method for determination of sugars and related substances, Analytical Chemistry, 28(3), 350-356.

Fang H.H.P. and Liu H. (2002), Effect of $\mathrm{pH}$ on hydrogen production from glucose by a mixed culture, Bioresource Technology, 82, 87-93.

Guo L., Li X.M., Bo X., Yang Q., Zeng G.M., Liao D. and Liu J.J. (2008), Impacts of sterilization, microwave and ultrasonication pretreatment on hydrogen producing using waste sludge, Bioresource Technology, 99, 3651-3658.

Guo L., Li X.M., Zeng G.M. and Zhou Y. (2010), Effective hydrogen production using waste sludge and its filtrate, Energy, 35, 3557-3562.
Khanal S.K., Chen W.H., Li L. and Sung S. (2004), Biological hydrogen production: effects of $\mathrm{pH}$ and intermediate products, International Journal of Hydrogen Energy, 29, 1123-1131.

Kotay S.H. and Das D. (2010), Microbial hydrogen production from sewage sludge bioaugmented with a constructed microbial consortium, International Journal of Hydrogen Energy, 35, 10653-10659.

Kotay S.M. and Das D. (2009), Novel dark fermentation involving bioaugmentation with constructed bacterial consortium for enhanced biohydrogen production from pretreated sewage sludge, International Journal of Hydrogen Energy, 34, 74897496.

Levin D.B., Pitt L. and Love M. (2004), Biohydrogen production: prospects and limitations to practical application, International Journal of Hydrogen Energy, 29, 173-185.

Lin Y.H., Juan M.L. and Hsien H.J. (2011), Effects of temperature and initial $\mathrm{pH}$ on biohydrogen production from foodprocessing wastewater using anaerobic mixed cultures, Biodegradation, 22, 551-563.

Liu Q., Zhang X., Yu L., Zhao A., Tai J., Liu J., Qian G. and Xu Z.P. (2011), Fermentative hydrogen production from fresh leachate in batch and continuous bioreactors, Bioresour. Technol., 102(9), 5411-5417.

Lowry O.H., Rosebrough N.J. and Farr A.L., et al. (1951), Protein measurement with the Folin phenol reagent, The Journal of Biological Chemistry, 1993, 265-275.

Nah I.W., Kang Y.W., Hwang K.Y. and Song W.K. (2000), Mechanical pretreatment of waste activated sludge for anaerobic digestion process, Water Resource, 34, 2362-2368.

Nicolau M., Dinsdale J.R. and Guwy A. (2008), Hydrogen production from sewage sludge using mixed microflora inoculum: Effect of $\mathrm{pH}$ and enzymatic pretreatment, Bioresource Technology, 99, 6325-6331.

Senturk I. and Buyukgungor H. (2010), An examination of used different waste materials and biohydrogen production methods, Sigma Journal of Engineering and Natural Sciences, 28(4), 369-395.

Senturk I. and Buyukgungor H. (2017), Biohydrogen production by anaerobic fermentation of sewage sludge - effect of initial $\mathrm{pH}$, Journal of Ecology and Environmental Sciences, 5(2), 107111.

Senturk I. and Buyukgungor H. (2017a), Biohydrogen production from sewage sludge by dark fermentation: the effects of adding inoculum and heat pretreatment, Energy and Environmental Engineering, 5(2), 54-57.

Tang G.L., Huang J., Sun Z.J., Tang Q., Yan C. and Liu G. (2008), Biohydrogen production from cattle wastewater by enriched anaerobic mixed consortia: influence of fermentation temperature and $\mathrm{pH}$, Journal of Bioscience and Bioengineering, 106(1), 80-87.

Wang C.C., Chang C.W., Chu C.P., Lee D.J., Chang B. and Liao C.S. (2003), Producing hydrogen from wastewater sludge by Clostridum bifermentans, Journal of Biotechnology, 102, 8392.

Wang J. and Wan W. (2011), Combined effects of temperature and $\mathrm{pH}$ on biohydrogen production by anaerobic digested sludge, Biomass and Bioenergy, 35, 3896-3901.

Xiao B. and Liu J. (2009), Biological hydrogen production from sterilized sewage sludge by anaerobic self-fermentation, Journal of Hazardous Materials, 168, 163-167. 